Bastian Lange, Berlin / Dominic Power, Uppsala / Lech Suwala, Berlin

\title{
Geographies of field-configuring events
}

\begin{abstract}
This paper treats the concept of 'field-configuring events' (FCE) and relates it to economic geographical research. The FCE approach attempts to draw attention to the role of events in fields of economic and social action and suggests that events can be important to introducing, structuring, maintaining and configuring new products, industrial standards, cultural artefacts and knowledge categories. The FCE approach has primarily been used to study the actors and networks associated with events such as trade shows, professional gatherings, technology contests, cultural tournaments, industrial exhibitions and business ceremonies: events where actors assemble to reveal novel products, develop industry designs, initiate cultural trends, create social networks, and allocate meaning to previously unfamiliar circumstances. In this introductory paper, we identify the main research trajectories in FCE and link these to economic geography by identifying some common lines of thinking apparent in economic geography, management and organisational studies. The paper moves on to investigate the nature of the "field", "configuration" and "events" from a geographic perspective, and to emphasize the role that space and power play as a structuring mechanisms in all three. We conclude that the FCE approach can function as a useful tool for geographical analysis of the increasing fluid and episodic contours of the contemporary space economy.
\end{abstract}

Keywords: field-configuring events, temporary organisations, conceptions of space, power relations, institutional work

\section{Introducing field-configuring events}

Economic geography has long drawn critical attention to the vital role that industrial contexts and localised milieus have for diverse aspects of economic life (BECATTINI 1991; CREVOISIER 2004). As a discipline we have explored and shed light upon the function of places and spaces in processes as diverse as the formation of untraded tacit knowledge or the establishment of economies of scale and scope through urbanisation (Howells 2002, 871; GERTLER 2003, 77; FAULCONBRIDGE 2006, 518). Much of our discipline has focused, however, on the regularised processes and operations in everyday life spaces that characterise the economies around us: the neighbourhood, the industrial district, the cluster, the city, the region, or the nation.

In this article, we humbly attempt to contribute to these debates by suggesting that whilst there are undoubtedly stable spatial contexts where most workers go to get their daily bread, we must also be aware that in relatively fleeting meetings, gatherings and events much of importance and significance is likely to happen. This introduction and the contributions to this special issue rest on the supposition that economic geography could benefit from complementing the fetishism of temporal and spatial fixity with a deeper acknowledgement of the temporal diversity and nature of spatial contexts (KNOBEN/OERLEMANS 2006, 84; FAULCONBRIDGE 2006, 537; LANGe/BÜtTNER 2010, 990). We are aware that time-geographical approaches have a long history in geography (cf. the work of Hägerstrand) and that in recent years numerous contributions have discussed the temporal nature of geographic processes (e.g. the special issue "Temporalität und Prozess" in this journal: IBERT/THIEL 2009). However, we argue that economic geography needs to widen its scope and conduct rigorous empirical research into the age-old observation that in certain times and places all that is solid melts into air.

We suggest that a useful addition to these existing debates might be gleamed through examining the lens of the recently introduced concept "field-configuring events" (FCE) by LAMPEL/ MEYER (2008). In doing this, we are aiming at testing how this concept may provide insights 
into the nature and the formulation of new geographies of production in knowledge-based as well as in creative industries. By examining the concept of FCE, we are motivated by an interest in conceptual as well as empirical work that focuses attention on the role of social architecture building and action in economic processes as well as in the cornerstones of temporal spaces. Accordingly we use the FCE approach to outline how and why geography needs to better incorporate different temporal scales alongside our traditional foci on lived and everyday routines.

The concept of field-configuring events is a relatively new approach mainly in management and organisation studies (see ASPERS/DARR 2011; LAMPEL/MEYer 2008; MoERAN / StRANDGAARD Pedersen 2011; Skov/Meier 2011; Thompson 2011; SCHÜsSLER et al. 2013) and has attracted recent attention within economic geography (e. g. LANGe 2011, 60; Suwala 2012, 153) where the concept of the field became prominent in the last 15 years (Sсотт 1999, 2006, 2010).

As a heuristic concept, the FCE approach attempts to theorise and emphasize dynamic aspects of emerging and declining fields of economic action as well as the social mechanisms that structure, maintain and configure the appearance of new products, industrial standards, knowledge categories which can be detected in institutional, organizational and professional fields (MEYer et al. 2005, 457; Sydow et al. 2004, 1479). LAMPEL/Meyer (2008) suggest that the concept attempts to bring us nearer to "temporary social organizations such as trade shows, professional gatherings, technology contests, cultural tournaments, industrial standards and business ceremonies in which people from diverse backgrounds and with different purposes assemble on a one-time, sporadic and irregular or periodically basis in order to reveal new products, develop industry standards, create social networks, acknowledge accomplishments, share and interpret information, or execute business" (2008, $1025 \mathrm{f}$.). The 'events' that are emphasized in this literature rest upon six characteristics (LAMPEL/MEYER 2008, 1027):

- Pooling of diverse actors in one place

- Bounded temporality (from hours to days)

- Spontaneous opportunities for direct social interaction

- Symbolic (dramaturgical, ceremonial, performative) constituent parts
- Incidents for information exchange and collective sense-making

- Reservoirs for social resources and manifold utilizations

This special issue attempts to identify some of the main research trajectories in FCE and to link them to economic geography by identifying particular common lines of thinking apparent in current research topics in economic geography and in management and organisational studies. The idea for this special issue is perhaps unsurprisingly originated from a series of events: a summer workshop in Berlin 2011; a special session at the RGS-IBG in Edinburgh in July 2012; and a panel discussion at the $1^{\text {st }}$ European Colloquium on Culture, Creativity and the Economy in Uppsala in October 2012. The contributors to this special issue (Jansson, Gibson/Bathelt, Schmidt/Brinks/Brinkhoff) use various theoretical frameworks and concepts to frame events and are far from wedded to the FCE approach. Nonetheless all papers share a concern to deal with the geographies and spaces for events and how events in turn affect economic space.

In the following we present an overview of existing and related literature from organization and management studies and economic geography. Then we analyse "field", "configuration" and "events" from a geographic perspective in an attempt to see whether there is anything that can be gained from FCE's use in economic geographical research. Finally some questions are raised for future research and papers of this special issue are introduced.

\section{Recent research on events and field-configuring events}

In recent years events have begun to attract considerable attention in various disciplines (Getz 1989; Hall 1989; Olds 1998; BitTneR 2001; Lampel 2011; LANGe 2011; McRobBie 2002; Stevenson et al. 2005). The focus here has usually been on man-made or organized events such as trade fairs, conferences, exhibitions and festivals. Research has not tended to emphasise disruptive natural events (e.g. floods, earthquakes), social movements (LOUNSBURY et al. 2003), or political unrest (GoLDSTONE 2004), though these undoubtedly have an enormous effect on economic processes and spaces. Rather stereotypically 'economic' or 'business' events characterised by interactivity have been studied 
most. This narrowness of focus can be justified perhaps in that events such as trade fairs or conferences are interesting spaces in themselves as well as ideal opportunities to study the wider industries they are organised by or are representative of. Practically all modern industries use interactive events and gatherings as catalysts for creativity, innovation and entrepreneurship in the search for 'novelty'. At the same time they can act as forges for new industries themselves (ZILBER 2007; LENA 2011; SCHÜSSLER et al. 2013; Skov/Meier 2011). Meyer, Gaba and Colwell proposed the term "field-configuring events" (FCEs) to approach these various types of structured events as "places where business cards are exchanged, networks are constructed, reputations are advanced, deals are struck, and standards are set" (MEYER et al. 2005, 467). Such "temporary social organizations" are interesting as spaces where we can study the shaping and development of professional, organizational, urban, regional or geographic fields (LAMPEL/ Meyer 2008; GLynn 2008).

These events are increasingly of interest to scholars, in management and organizational studies as well as in economic geography. Although it should be noted that it is almost impossible to draw a distinct line between economic geography, management and organisational studies with regard to FCE in practice, we pursue this academic distinction here in order to highlight subtle differences between the disciplines at stake in general and the value-added for economic geography in particular.

\section{Events in organization studies}

The term field-configuring events is well rooted in the field of organizational studies. For scholars interested in developing approaches to the structuring and the organization of economic activities the FCE approach has proved popular in recent years. This approach to "field-configuring events as structuring mechanisms" (LAMPEL/ MeYer 2008, 1025) is broadly anchored in organizational institutionalism or neo-institutionalism that stress the role of organisational fields (DiMaggio/Powell 1983).

Scholars in organisational studies have noted that certain occasions involve special types of ceremonial and dramaturgical strategies for structuring events by embracing and creating fields outside of ordinary professional practices or industrial patterns. As a consequence, they explicitly call for an in-depth investigation of framing and configuring processes that grant those events their idiosyncratic nature (MoERAN 2011). Since such events - even if often organized and structured - differ from usual arrangements in markets, networks and hierarchies, peculiar structuring mechanisms are needed in order to facilitate activities such as information exchange, collective sense-making, and the generation of social and reputational resources (LAMPEL/MEYER 2008, 1027). BECKERT (2010) highlights three types of social structures, namely the interrelations of institutions, social networks, and cognition as the main drivers for field configuring. These, however, require particular institutionalized rules (regulative, normative, cultural-cognitive) - even in organized matchmaking events with various private, public or civic sector groups (RÜLING / STRANDGAARD Pedersen 2010, 318) - that are negotiated by actors in novel and unexpected constellations for the purpose of collective sense-making (SCOTT 1994, 2003). Organisation scholars often mention enabling capacities, forces, factors as well as environments or even discursive spaces as structuring mechanisms (see MCINEREY 2008, 1091; HARDY/MAGUIRE 2010, 1372).

One of the most frequently adopted concepts used in regard to how structuring or change in fields is enabled is that of institutional work (LAWRENCE/SudDABY 2006; BuRKe/Knight 2011; MÖLLERING 2011). Institutional work involves "the purposive action of individuals and organizations aimed at creating, maintaining and disrupting institutions" (LAWRENCE/SUDDABY 2006, 215). All institutions have a central logic and sustain meaning through "an empirically and historically variable combination of explicit norms governing behaviour" (ALFORD/FrIEDLAND 1985, 428) based on supra-organizational repetitive patterns of human agency (material, symbolic) (FrIEDLAND/ALFORD 1991, 232).

Despite being organized, industry events can be liminal and transversal spaces of coproduction formed among various agents with different backgrounds and interests. Unexpected encounters bring together diverse actors outside pre-scripted routines and involve institutional work so that new constellations of collective sense-making can emerge. The opportunity to escape from everyday routines make events important arenas for new perspectives, creativity, innovation, knowledge exchange and unanticipated contacts. This may be especially true 
for identity formation in new markets (NAVIS/ GLYNN 2010) where the coproduction of new identifying codes is important to how audiences can estimate reputation, information and ultimately legitimacy. In cultural product markets, for example, events play an important role due to the uncertainty involved in ascribing shared meanings to and valuating creative commodities (SuwALA 2012, 140). Existing research confirms indirectly that institutional work is needed in events such as art fairs and biennales, film and music festivals to enable collective sense-making as well as knowledge trades or exchanges (Delacour/LeCa 2011, 49; EnTwistle/RocaMORA 2006, 735; JONES et al. 2005, 893).

In summary, in organizational studies events have been seen to play a principal role in structuring new technologies, industries, institutions and markets (GARUD 2008; LAMPEL/MEYER 2008; Delacour/LeCa 2011; NAVis/GLynn 2011).

\section{Events in management studies}

The role of field-configuring events is also an emerging theme in management studies. Though the divide between organisational and management studies is more a heuristic tool than a real schism, the focus in management studies is less upon structuring and configuring the field itself and more on the agencies and strategies underpinning power relations within fields (see LEVY/ SCULLY 2007). Here events have been seen to act as arenas for power relations that depend on the shared management and negotiation of institutions, resources, routines, and strategies.

The interactions and relations between actors has been suggested to be played out in "orders of worth" (MCINERNEY 2008, 1092), "tournaments of value" (MOERAN 2011, 119), or "meta races" (GARUD 2008, 1081), where criteria for victory are constantly negotiated during events. Management studies likewise acknowledge the importance of space by introducing manifold, but sometimes arbitrary, expressions like "arenas" (LAMPEL 2011, 337), or "ecologies" (RÜLING / StRANDGaARD Pedersen 2010, 319) to invoke the enabling environments associated with power relations. In other words, these studies are primarily concerned with actors' strategies during the events that configure market relations (MCINERNEY 2008).

In events such as conferences individual economic agents, in the absence of their anticipated or habitual professional routines, must court for attention and are likely to encounter unexpected opportunities as well as hindrances. If this is the case then management decisions have to face planning, organizing, commanding and/or coordinating tasks within unstructured and undetermined environments that are almost impossible to control. The resulting ambiguity calls for solutions which examine rituals that deal with the distribution of power relations among individuals in such settings (GARUD 2008, 1063), rule making procedures (MCINERNEY 2008, 1090), standard setting practices (HARDY/MAGUIRE 2010, 1366), or reputation building strategies (GLÜCKLER 2007, 952) in order to minimize complexities and reduce uncertainties in these unsettled, instable and fragile environments.

Special attention - although not exclusively (for examples from other industries see MARQUIS/ DAVIS 2005) - has been paid to industries where intangible assets such as reputation, fashion or symbolic capital are important (SKOv 2006, 765; SKov/MeIER 2011, 274). In this context FCE have been seen to play a role in selection mechanisms through being venues for the arbitration of different set of values (MOERAN / STRANDGAARD Pedersen 2011). Paleo/Wijnberg (2006) for instance, have taken a closer look at music festivals and concerts and argue that these venues are "platforms" for showing musicians and for communicating musicians' cultural newness. Other contributors suggest that such music festivals and events are increasingly important forums for the formation and contestation of discourses on copyright and copyright strategies (DoBusch/ SCHÜSSLER 2010; SCHÜSSLER/DOBUSCH 2013).

ANAND/Watson (2004, 60) have highlighted award ceremonies such as The Oscars or the Man Booker Prize as so-called "tournament rituals". These regular events provide reputation and positioning in social networks and professional fields. Moreover, award ceremonies can spillover to others fields, e.g. when actors' red carpet clothing becomes an advertising channel for fashion.

What these contributions from management studies admirably underline is the importance of understanding power relations and actors' strategic involvement in events. This literature shows that behavioural strategies during events are very different compared to behaviour in internal firm milieus or direct firm-client relationships that managers spent most of their time working 
within. Events are not only about the field and its institutions - though they are about exactly this too - but also they are fields for actors, agents and power relations.

\section{Events in economic geography}

If management and organizational studies have allocated limited time to the complexities of space and place when considering events, then economic geography may be considered to have allocated limited space for the complexities of time and temporality. However, events, in particular trade fairs, and their relations to cluster theory have become a leading topic for economic geography in recent years. Economic geographers have conceptualized professional gatherings as "temporary clusters" (MASKELl et al. 2006, 2) or "cyclical clusters" (POWER/JANSSON 2008, 426). Scholars have suggested that many of the knowledge dynamics central to clustering and agglomeration may be clearly seen at trade fairs and conventions leading to the suggestion that such events can constitute "temporary clusters" (e.g. BATHELt 2006; BAthelt et al. 2004; MASKell et al. 2004, 2006; SCHULDT/BATHELT 2009).

MASKELL et al. $(2006,998)$ linked trade fairs to temporary clusters "because they are characterized by knowledge-exchanging mechanisms similar to those found in permanent clusters, albeit in a short-lived and intensified form. Their work makes a convincing argument for the role of trade fairs as knowledge exchange and creation platforms for industries where global links are important. Furthermore, they argue that fairs represent important complementary events, even in industries where strong localized clusters dominate knowledge dynamics and production. These authors, among others (e.g. STORPER/ VENABLES 2004), have pointed out that the importance of face-to-face interaction in temporary clusters may be a substitute and/or possible strategy to complement local interaction in permanent clusters. Cultural anthropologist SKOV $(2006,765)$ mirrors this idea with her use of the metaphor "temporary townships" in order to shed light on various kinds of spatialised social encounters of intense knowledge exchange, social network building, and idea facilitation comparable to social interaction processes that take place in more durable and lasting regional clusters.

Following this line of thinking, these organized events are - to a certain degree - spatially (and temporally) limited agglomerations of selected actors with manifold and unique opportunities for exchange and perception. The temporary clusters or townships, however, are largely portrayals of events as singular happenings. The approach tends towards considering events as isolated phenomena in the conventional life of localized clusters and firms. In many cases, it is undoubtedly true that events are simply occasional complements to the real work that happens locally everyday. However, in many industries there is the possibility that professional events may be arranged in an almost continual circuit; and that it could be in such circuits that the economic field is most profoundly configured. It is against this background that POWER/ JANSSON (2008) and JANSSON/POWER (2010) introduce the idea of "cyclical clusters" to argue that events such as conferences or trade fairs rest upon complexes of overlapping spaces that are socially timed and spatially arranged in such a way that social spaces can be reproduced, reenacted and renewed over time. The timing and repetition of social events mean that conferences and trade fairs are far from a temporary exception and much more regular pit stops on well travelled global circuits. This would entail that although e.g. actual fairs, conferences are shortlived events, but their presence in the business cycle has lasting consequences for the organization of markets and industries and the firms that make up industries.

Cycles of events in certain industries - from automobiles to film - are not only regular industrial meeting points but also platforms and channels for communication and broadcasting different types of messages, brands or movements that consumers follow closely. The importance of major film award ceremonies and festivals to film industry release strategies indicate that cyclical events can be important to the field in the broadest sense and not just industry insiders.

The role of the host region or city is another part of this equation that geographers have examined. The success of events' communicative aspects depends to a certain extent on local forms of capital such as a city's status and reputation. Place brands and narratives are increasingly sought after by events, which understand that there is an important positive relationship between events and places (JANSSON/POWER 2010; PIKE 2011). Equally cities themselves commonly compete with each other for events likely to confer economic or branding advantages: e.g. com- 
petitions to be Olympic hosts; or how Berlin and Barcelona have competed to host the fashion fair Bread \& Butter (SKov/Meier 2011). A long term connection between a place and the temporary can prove vital for wider global fields of culture and value, for instance, when local scene-based electronic music genres are considered as "local divisions" and a local resource that can be capitalized for marketing reason for the benefit of a global and not a local market (LANGE/BÜRKNER 2013, $160 \mathrm{f}$.).

It should be mentioned that besides authors focusing explicitly on events of one type or another, there are many that have a tight focus on temporary phenomena in general. GRABHER (2004), amongst others, has drawn attention to the fact that in many sectors of the economy project-based working is now common. The formation, enactment and dissolution of a project - aiming at e.g. producing a movie or a theatre play - can certainly be considered an event and the literature on project ecologies from a spatial perspective (e.g. GRABHER 2002) shares many parallels with literature that tries to contextualise or locate events in more stable settings. In short, geography is far from ignorant of accounting for the fleeting or episodic but more needs to be done.

\section{The state of the art-searching for common ground}

Despite different perspectives on FCE and theory related to the role of events, there is some common ground concerning the economic and industrial function of events. There is obvious consensus that events can allow for the bridging of and dealing with uncertainties via different structuring mechanisms (spatial, managerial, organisational) on the one hand, but simultaneously allowing ambiguities to generate change (creativity and innovation) on the other. This inference has been investigated mostly through contributions from organisational studies looking at field or identity formation, maintenance, maturity, dissolution; in management studies by considering the establishment of rules, norms or customs, defining industry standards or curating cultural artefacts in tournaments; and in economic geography by visualizing different spatialities and scales as enablers and/or frames for field (markets or events) formation (Tab. 1).

\section{Economic geography and field-configuring events}

FCE is interesting for economic geographers because as an approach it has explicitly contained a plea to include space as an elementary part of explaining economic actions and processes. LAMPEL/MAYer $(2008,1027)$ describe FCE as events where actors from diverse professional, organizational, and geographical backgrounds assemble in and necessitate one location. For economic geography, of course, space is not an easy to handle one-dimensional phenomenon or locational fix, but rather requires a differentiated and elaborated analysis. This for us means that it is more appropriate to talk in terms of multiple and processional geographies of FCE. Moreover we suggest that understandings of the complex geographies of FCE need to take into account cognitive, social and economic structuring mechanisms in such spaces. Overall, it

Tab. 1: Field-configuring events in different disciplines

\begin{tabular}{|c|c|c|c|}
\hline & Economic Geography & Management Studies & Organisation Studies \\
\hline $\begin{array}{l}\text { Main point of } \\
\text { interest }\end{array}$ & $\begin{array}{l}\text { Geographies of fields or } \\
\text { events }\end{array}$ & $\begin{array}{l}\text { Power relations within } \\
\text { fields }\end{array}$ & $\begin{array}{l}\text { Structuring of fields (market), } \\
\text { events }\end{array}$ \\
\hline Dimensions & $\begin{array}{l}\text { Temporary } \\
\text { agglomeration/isolation, } \\
\text { temporary } \\
\text { proximity/distance }\end{array}$ & $\begin{array}{l}\text { Resources, routines } \\
\text { (practices), institutions } \\
\text { (rules, standards), com- } \\
\text { petition (tournaments) }\end{array}$ & $\begin{array}{l}\text { Market formation, segmentation, } \\
\text { fragmentation, dissolution; } \\
\text { identity building (reputation, } \\
\text { branding, knowledge etc.) }\end{array}$ \\
\hline Key contributions & $\begin{array}{l}\text { SCOTt 1999, 2006, 2010; } \\
\text { GRABHER 2002, 2004; } \\
\text { BATHELT et al. 2004; BATHELT } \\
\text { 2006; MASKELL et al. 2006; } \\
\text { POWER/JANSSON 2008; } \\
\text { LANGE 2011; SUWALA } 2012\end{array}$ & $\begin{array}{l}\text { ANAND/WATSON 2004; } \\
\text { MCINERNEY 2008; } \\
\text { DOBUSCH/SCHÜSSLER } \\
\text { 2010; MOERAN 2011; } \\
\text { LAMPEL } 2011\end{array}$ & $\begin{array}{l}\text { LAMPEL/MEYER 2008; GARUd } \\
\text { 2008; NAVIS/GLYNN 2011; } \\
\text { DELACOUR/LECA 2011; } \\
\text { LENA 2011; THOMPSON } 2011\end{array}$ \\
\hline
\end{tabular}


seems that the variety of dimensions implicit in FCE means we need to focus on the recursive relationships between event spatialities and their economic significance. Asking some very basic questions may help us here: Who is in charge of organizing them? How are they formed? What happens during them? Why are they important for particular interests and industries? What effect they may have on other processes? When and where do they take place? In the following we examine the spatialities (the where-question) as well as the particular idea of field-configuring events and its possible application in economic geography (all other questions).

\section{In the search for spatialities in FCE}

In general, the organisational and management literatures almost entirely neglect the spatial dimension. When space is dealt with there is a tendency to apply rather simplistic notions of scales and/or space, e.g. by placing temporary events within certain spatial scales (e.g. local, global) or assuming fixed or substantive spatial entities such as quarters, cities or regions. Moreover, there is an uncertainty how spatially bounded contexts for social interaction work in one place but not in another. As LAMPEL/Meyer (2008, $1027)$ point out, the "current theory of field formation and development seems to focus almost exclusively on global and continuous processes that drive field evolution, while paying little attention to discontinuous and localized processes such as field-configuring events that play an important, albeit intermittent, role in shaping the evolution of fields". What is missing are differentiated conceptualisations of space, nuanced understandings of the particularity of places and spatial perceptions, and understandings of the complexity of spatial scales.

Despite these lacunae, there is a growing interest within organisational studies in the spatial dimension (BEYES/STEYAERT 2011; GLYNN 2008; Hernes 2003; HJorth 2004, 2005; Steyaert/ KATZ 2004). In this regard, HeRnES $(2003,277)$ has argued for a shift from the term context to that of space as the central parameter for understanding the logics and social embedding of organizations. Similarly, HJORTH $(2004,418)$ explicitly introduced the idea of studying entrepreneurship through "spatial concepts" (see also Steyaert/HJorth 2003; Steyaert/Katz 2004). By suggesting "space is where disciplining/normalizing forces come to play as demarcating the possible and proper place", HJORTH (2004,
419) portrays spatiality as a complex and difficult concept within the context of organizational and entrepreneurial studies. Referring to Foucault's concept of heterotopia (FoUCAULT 2000 [1984], 179) he describes how something occupies a place in which it normally should not be in. This notion of distortion allows for a broader description of spaces as places. In this respect, places are shaped by social dynamics and distinct strategies as employed by DE CERTEAU (1988). HJORTH $(2004,393)$ attempts to localize events by discussing how market participants form events in order to provide unique "spaces for play". Equally, RÜLING / STRANDGAARD PEDERSEN $(2010,319)$ discuss events as temporary "ecologies of learning", and LAMPEL (2011) emphasizes localized event specificity with his concept of events as "arenas of emergence".

For many scholars in economic geography the focus of spatial analysis has shifted from a deterministic or functional perspective towards understanding the relationships governing cultural codes, social entities such as project teams, meetings, gatherings and events as well as culturally coded identities (e.g. FAULCONBRIDGE 2008; GLÜCKLER 2006; LANGE et al. 2008; SUWALA 2012). Spatially relevant patterns of activity, networks of specific actions, and the creation of formal or at least temporary institutions are always coordinated and mediated by symbols, processes of communication and modes of governance (HelBrecht 1998; Pratt 2009). Such approaches are often based on the notion of locally bounded and routed creative, social and cultural capital as a means to mobilize existing and new opportunities (FLETCHER 2006). This can take place through processes of recoding with a view to designing new planning strategies to solve spatially relevant problems (HELBRECHT 1998). In both temporary and permanent conceptions of proximity, space is understood as a form of physical, cultural, or institutional proximity between local market participants (KNOBEN/OERLEMANS 2006). Often, however, this local proximity is already taken as a fixed predetermined entity. Scholars (such as IBERT 2006; FAULCONBRIDGE 2008; GrabHer 2004; LANGE/BÜtTNER 2010; SUWALA 2012) have argued against this static and substantive perception of proximity and for notions of proximity that encompass the sequences of practices and processes that lead to the formation of more dynamic and relational concepts when organizing local/trans-local networks, exchanges, and institutions, an idea that echoes FCE notion of configuration. The sociol- 
ogist Löw (2008) also takes up this argument for understanding the reproduction of space as processual and therein constantly emergent. She posits that space is an act of synthesis based on specific strategies and tactics of individuals who arrange social goods and bodies in relation to each other in an on-going process of "spacing". Building on this processional notion, we ask whether FCE can help us to think about how temporary spatial proximity is orchestrated, steered and personalized as well as materialized in a particular region or city. Or whether the concept sheds light upon our understanding how and if temporary arenas are of importance to more permanent market structures.

There are a variety of approaches to space in this literature. Substantive approaches exist defining space by virtue of the transactions occurring at a time and place - such as the Grammy awards, the Frankfurt book fair or the major film festivals in Cannes, Berlin, and Venice (e.g. Mezias et al. 2011). Such tight spatial conceptions however seems of limited value for explaining how these events might contribute to the structures or distributions of power and agency in fields or vice versa. There are relational conceptions of space that avoid a priori spatial frames and emphasize interaction in space - "places where business cards are exchanged" (MEYER et al. $2005,467)$ - leaving everything to social agency. There are cognitive conceptions of space that tend to rest upon or highlight the dramaturgical and ceremonial symbols, images, and languages in events conceived as "discourse spaces" (HARDY/MAGUiRE 2010, 1372). Still other authors attempt to relate the temporary or cyclical to the less episodic daily life, learning and processes of firms and industries.

In short, we feel that there is a need for better theorization and operationalization of space in relation to FCE and the study of events in general. The literature from organizational and management perspectives needs complementing with a much more explicit but nuanced understanding of proximity and space. Simultaneously, we suggest that despite some exciting contributions, economic geography is still far from providing a comprehensive framework with regard to the spatialities or proximities of fields or events.

\section{In the search for fields, configuration and events in economic geography}

As noted above economic geography has begun to explicitly theorise and study the role of events in economic space. The discipline has long been fascinated by proximity, urbanization and localization economies but has, however, largely assumed these accrue through regular everyday proximity. If economic geography has, as we suggest, tended to look for situated and stable economic spaces: What then with disruptive events or crises? What of wider fields of endeavour beyond the region or production network? What of power and agency that attempt to challenge situated status quos? The field-configuring events approach addresses, though does not answer, many of these questions directly and in doing so draws attention to three issues we think ought to be of renewed importance to economic geography.

First, economic geography needs to deal explicitly with events. Economic geography and related disciplines have only recently begun to engage theoretically with the conceptualisation and empirical examination of the event and its role in shaping economic activities and geographies (GLYNN 2008; HaRdy/Maguire 2010; LAMPEL 2011; Moeran / Strandgaard Pedersen 2011; Skov/MeIER 2011) but this is something that

Tab. 2: Conceptions of space with regard towards events

\begin{tabular}{|c|c|c|}
\hline Substantive conceptions (economic) & Relational conceptions (social) & Cognitive conceptions \\
\hline $\begin{array}{l}\text { "FCE assemble in one location } \\
\text { actors from diverse ..." } \\
\text { (LAMPEL/MEYER 2008, 1027) }\end{array}$ & $\begin{array}{l}\text { "Places where business cards are ex- } \\
\text { changed" (MEYER et al. 2005, 467), } \\
\text { "temporary townships" (SKOV 2006, 765), } \\
\text { "spaces for play" (HJORTH 2004, 393) }\end{array}$ & $\begin{array}{l}\text { "Discourse spaces" } \\
\text { (HARDY/MAGUIRE 2010, 1372) }\end{array}$ \\
\hline \multicolumn{3}{|c|}{ "Temporary clusters" (MASKELL et al. 2006, 2) } \\
\hline & \multicolumn{2}{|c|}{ "Cyclical clusters as overlapping spaces" (PoweR/JANSSON 2008, 425) } \\
\hline "Ecologies of & rning" (RÜLING / STRANDGAARD PEDERSEN 2 & $10,319)$ \\
\hline
\end{tabular}

Source: own compilation 
needs doing. In general, events can be understood as "major one-time or recurring occasions of limited durability, arranged primarily to enhance awareness, attention, appeal and/or profitability for a particular purpose by its uniqueness, status, timely and/or spatially significance in the short and/or long run" (HALL 1989, 23). Different classification schemes are imaginable along the lines of the above-mentioned characteristics of events, e. g. planned/unplanned, natural/manmade. Moreover, classifying events involves the spatial scales of events: e.g. mega-events, international events, or community events (LEY/ OLDS 1988; HALL 1989).

However, thinking about events reminds us also of the temporal dimension, and that change is a constant if variable feature of the industrial landscape. While change can be subtle and built upon a longue durée, equally it can be episodic and sporadic. Change often occurs in and around specific events. The profound shocks created by events such as the fall of the COMECON, the advent of the world wide web, the rise of outsourcing and offshoring, or the development of advanced and easy to access communication technologies awaken us to the potential for systemic change. Whilst on a lesser scale momentary flashes of inspiration or short-lived meetings of minds can have lasting effects. Perhaps due to the organisational and spatial reshaping that ensue from shortening waves of technological change, cultural trends or production cycles, it seems to many that landscapes are being redrawn and rewired at increasing frequency. Indeed, there is a widespread perception of volatility, mobility, rapid change and obsolescence that seems to underpin the working lives and strategic assumptions characterising many workers and industries (BAUMAN 2005).

In the cultural and creative industries, recent digital transitions have upended established business models, blurred or erased industrial boundaries, ushered in new entrants and added to the uncertainty already built into industries that deal with markets based on serving consumers ever changing desires, tastes, fashions and fads (Power/ScotT 2004). The same evolution can also be observed in high-tech industries and knowledge-intensive business services where the converging of professional practices led to composite labels like TIME (telecommunication, information, media and electronics) (LANG 2003) or FIRE (finance, insurance and real estate) industries (SASSEN 1991). Whilst events, either episodic or unique, may or may not play important roles in the course of forming emerging economic geographies, they do allow researchers important focused periods within which wider industrial change can be studied and analysed.

Having said all the above, focusing on the event risks leaving out other perspectives and empirical areas of importance to understand change. As SCHÜSSLER et al. $(2013,1)$ suggest, "although field-configuring events have been highlighted as catalysts of institutional change, we still know little about the specific conditions that allow such change to occur". The issue of the preconditions for change and its embedding means that research focused on the event alone will never fully succeed. We must understand the existence of complementary approaches and must try to link events to other types of spaces or processes.

Lastly, it should not be overlooked that a significant share of economic processes at work are executed in stable and almost rational environments where certain economic stakeholders (e.g. multinational enterprises) exert strict coordination and control mechanisms on weaker economic actors to form future decisions as calculable and predictable as possible (IAMMARINO/MCCANN 2013). Even though events are important and offer a good opportunity to study microcosms of wider processes focusing on events leaves out much and blinkers us to many important processes.

Second, placing the matter of configuration centre stage focuses us on issues of power and agency. In recent years economic geography has increasingly seen industrial landscapes through the lenses of innovation and knowledge diffusion, through the notion that network connections are as important as nodal units, through evolutionary and ecological metaphors, and through ideas of interdependent relations of cooperation and competition (PORTER 1990; LUNDVALL 1992). Much of the work grounded in these approaches tends to implicitly accept and build upon the idea that inequality of power and possibility are innate background features of economic space; rather than focusing primary attention on the political economy of action based on the acquisition, dividends and reproduction of unequal power relations. Configuration is a notion that is all about who, when, how and why action is taken to change a field. Here, economic geography can learn from organisational studies where 
the concept of "institutional work" (LAWRENCE/ SUDDABY 2006; MÖLLERING 2011) allows for the analysis of processes and alternations by actors themselves. Unlike overwhelmingly descriptive concepts such as temporary clusters (MASKELL et al. 2006) or cyclical clusters (POWER/JANSSON 2008), FCE theory pushes us to explain the making and taking by actors of power, space, and possibility. In other words, this approach reminds us to frame fields of action and to ask why stakeholders pursue certain economic aims across space. Without this framing different conceivable actions cannot be adequately described, explained or designed (CALLON 1998, 17). Since fields are not apparent in everyday and routinized activities, they need multiple - often localized - framing mechanisms to bring them to light, to raise attention, to stand out in the crowd, or simply to configure them (MOERAN 2011, 8; SUWALA 2012, 201).

Third, if FCE theory embraces, structuring, power and agency as central to economic landscapes it does so by linking ideas of configuration with the wider notion of the 'field'. Bourdieu (1984) proposes the field as the setting in which individuals and their social positions are located and fought for, and as the setting in which economic actors and their relative positions, but also those of the materialized products that they produce are located. The notion of fields is to us an attractive one in that it focuses attention on actors within wider - not only relationally defined - environments, on the idea that actors' behaviour is dynamically interrelated and therein constitutive of this wider environment, and on the idea that actors' strategic aims seldom benefit all equally (Bourdieu 1984). Those conflicting goals mean that we need to try to take into account an understanding of resources held, routines practiced, rules and standards negotiated by actors in the respective fields of action. Insights from management studies about competition and cooperation strategies (e. g. in tournaments; see MCINERNEY 2008) could help us to better understand the logics of competition and power in fields. Such notions place emphasis on actants, actions and relationships rather than defining economic areas by virtue of dominant technologies (e.g. the recorded music industry) or core products (e.g. the film industry) (SCOTT 2005).

Field conceptualizations help to reveal different types of non-routinized activities on individual, community and institutions levels (SuwALA 2012, 205). Such insights combined with a specific geographical lens where perception, interaction and agglomeration by themselves or combined act as genuine spatial structuring mechanisms could lead to new insights into field evolution (SuwaLA 2012, 196). This spatiality of fields or the field in space is centrally about the processes by which actors define settings themselves through their actions - their selective actions to position themselves or their products relative to significant others - and how in these settings their actions are primarily aligned through economic relations as well as social, political and cultural relations. Thinking about fields, for us, recognises the diversity of actors involved in shaping economic spaces and that the accrual and utilisation of power is what characterises fields, and perhaps economic geography, above all else.

A critical economic geography can benefit, we think, from a more explicit focus on who it is that configures the fields we study, why they do this, and what their reasons are. This involves taking into account both the spatial and temporal dimensions of field configuration: when and where fields are created, maintained or dissolved and how actors develop and operationalize spatial and temporal strategies to get what they suppose they want. Thinking in terms of field-configuring events places attention on the interaction of space and time, field and event, but crucially on the framing issue of configuration. Configuration should be a key word for those of us interested in economic and industrial landscapes and dynamics. A focus on configuration leads us to think about the actors and strategies that frame or shape landscapes and dynamics, and crucially on the relations and dynamics of power in shaping economic geography. Geographers have a unique contribution to make to more nuanced and profound understandings of temporality and power because relations and distance are central here. How actors are proximate, how spaces and events are connected, and how spaces are hierarchically related are profoundly important questions and profoundly geographic.

\section{Outline of the special issue}

In addition to this introductory paper the special issue contains three original contributions. All papers deal with events in one or another way, and though they do not all deal with FCE in specific, they all demonstrate the benefits to eco- 
nomic geography of thinking in less routinized ways about the temporality and spatiality of the economy.

The first paper by Johan Jansson discusses the role of temporary spaces and events for creativity and value in fine art. Few studies on temporary spaces focus on the cultural industries in general and the art market in particular despite art being a good case study area for understanding the role of temporary spaces in value creation processes. In his paper, Jansson discusses how in primary art markets much activity happens in temporary spaces, events and exhibitions organised by galleries for the purpose of selling and promoting primary art and artists. He suggests that temporary spaces and events constitute both a characteristic feature of the art market and important spaces for creating both cultural and economic values. Events, temporary spaces and exhibitions provide a socially embedded platform where the value of art and artworks are negotiated in the interplay between various actors such as artists, gallerists, critics and art buyers. Empirically, the paper is based on a study of Swedish art galleries and it is suggested that galleries work strategically with spatial form and timed events to create economic and cultural value for themselves and for the artists and artwork they represent: galleries enable spaces for a multitude of events crucial to the formation of art fields.

The second paper by Rachael Gibson and Harald Bathelt investigates the role of trade fairs in structuring processes of knowledge circulation among producers, users, suppliers and other participants in an industry or technology field. While major field configuration activities, in the sense of a discontinuous shift in the technological trajectory or consumption pattern, are unlikely to occur at trade fairs, such events often have a more nuanced, yet significant, impact on their respective field. Different trade fairs within a field partly overlap in terms of their goals, audiences and set-ups; yet they generally serve different functions and are characterized by diverse practices of knowledge generation. The paper uses the case of the global trade fair cycle of the lighting industry to illustrate this and builds upon an impressive dataset of semi-structured interviews and systematic observations conducted at trade fairs in North America and at a major German trade fair. Due to the decentralized nature of knowledge circulation, the cumulative characteristics of learning processes and the sequence of events, Gibson/Bathelt argue that trade fairs may be better viewed as fieldreproducing events rather than field-configuring events.

The last paper by Suntje Schmidt, Verena Brinks and Sascha Brinkhoff analyzes what they call "innovation and creativity labs" which are defined as experimentation fields and crystallization points for temporary practices that generate product, process, and organizational innovations. The authors argue that in recent years there has been a wealth of speculation on the openness, democratization, flexibilization, commercialization and decentralization of innovation and therein the role of events and temporary interactive spaces needs to come to the fore. Against this background they discuss the spatial and organizational development of innovation and creativity labs in Berlin and the role these labs could play in generating creative fields in Berlin. The empirical evidence presented highlights the variety of temporary spatial configurations seen in the city and its creative fields: grassroots labs, co-working, studios, and incubator and acceleration spaces. Schmidt/Brinks/Brinkhoff conclude by arguing that economic geography needs to explore such spatial configurations and their role in emerging urban creative and innovation fields.

\section{Conclusion}

This introduction to the special issue has tried to draw attention to a growing area of work in organisational, management, and geographical studies that highlight thinking in terms of field-configuring events. We have suggested that this approach makes an interesting contribution, for instance, by focusing our attention on the structuring mechanisms active in fields of action and how actors strategically work to obtain power in order to minimize complexities and reduce uncertainties in unsettled market environments. We have suggested that there are a number of unresolved issues associated with the approach and with research on events in general and that how we conceptualize them as spaces is one such major issue. For our part we would suggest that there are multiple spatialities and geographies at issue and that easy packaging of events into metaphoric arenas or platforms does neither help with the need to take cognitive, social and economic structuring mechanisms and power relations into account, nor with the need to conceptualize how events relate to each other and to other economic spaces. 
Introducing the field-configuring event approach to economic geography is not simply out of an interest in events. Rather we have argued that this approach alerts us to the need to think more deeply and generally about events and time but also beyond the event: about the fields of endeavour that firms, industries and spaces are involved in, about the value of a more explicit focus on how power relations are constructed, negotiated or imposed, and about the active framing and strategic configuration of space. Spatial approaches that stress a temporal complexity as well as embrace a consistent focus on the dynamics of configuration and power are approaches we suggest economic geography might not seek solace in but can at least seek some inspiration from.

\section{References}

Alford, R. R. / Friedland, R. (1985): Powers of theory. Capitalism, the state, and democracy. Cambridge.

ANAND, N./WATson, M.A. (2004): Tournament rituals in the evolution of fields. The case of the Grammy Awards. In: Academy of Management Journal, (47)1, 59-80.

Aspers, P. / DARR, A. (2011): Trade shows and the creation of market and industry. In: The Sociological Review, (59)4, $758-778$

Audretsch, D. B. / Feldman, M. P. (1996): Innovative clusters and the industry life cycle. In: Review of Industrial Organization, (11)2, 253-273.

Bathelt, H. (2006): Geographies of production. Growth regimes in spatial perspective 3: Toward a relational view of economic action and policy. In: Progress in Human Geography, (30)2, 223-236.

Bathelt, H. / Malmberg, A. / MAskell, P. (2004): Clusters and knowledge. Local buzz, global pipelines and the process of knowledge creation. In: Progress in Human Geography, (28)1, 31-56.

Bauman, Z. (2005): Liquid life. Cambridge.

Becattini, G. (1991): The industrial district as a creative milieu. In: Benko, J./ Dunford, M. (Eds.): Industrial change and regional development. The transformation of new industrial spaces. London/ New York, 102-116.

BeCKert, J. (2010): How do fields change? The interrelations of institutions, networks, and cognition in the dynamics of markets. In: Organization Studies, (31)5, 605-627.

Beyes, T. / Steyaert, C. (2011): Spacing organization. Nonrepresentational theory and performing organizational space. In: Organization, (19)1, 45-61.

BitTNER, R. (2001): Die Stadt als Event. Zur Konstruktion urbaner Erlebnisräume. Frankfurt am Main. (Edition Bauhaus 10).

Bourdieu, P. (1984): Distinction. A social critique of the judgement of taste. London.

Burke, G. / KNIGHT, L. (2011): Institutional work at fieldconfiguring events. Shaping industry change within sus- tainable transitions. Lund. (Paper prepared for the 2nd International Conference on Sustainability Transitions, June 13-15, 2011, Lund).

Callon, M. (1998): The embeddedness of economic markets in economics. In: Callon, M. (Ed.). The laws of the markets. Sociological review monograph, Blackwell/London, 1-57.

de Certeau, M. (1988): Kunst des Handelns. Berlin. (Internationaler Merve-Diskurs 140)

Crevoisier, O. (2004): The innovative milieus approach. Toward a territorialized understanding of the economy? In: Economic Geography, (80)4, 367-380.

Davis, G.F. / MARQuis, C. (2005): Prospects for organization theory in the early twenty-first century. Institutional fields and mechanisms. In: Organization Science, 16(4), 332-343.

Delacour, H. / LecA, B. (2011): The decline and fall of the Paris salon. A study of the deinstitutionalization process of a field configuring event in the cultural activities. In: M@n@ gement, (14)1, 47-78.

DiMaggio, P. J./ Powell, W. W. (1983): The iron cage revisited. Institutional isomorphism and collective rationality in organizational fields. In: American Sociological Review, (48)2, 147-160.

Dobusch, L. / SchüssLer, E. (2010): Transnational change through field-configuring events. The copyright discourse in the German music industry. Loveno di Menaggio. (Paper prepared for the Fourth Conference on Economic Sociology and Political Economy - Transnational copyright: organisation, mobilisation and law, June 12-15, 2010, Villa Vigoni, Italy).

Entwistle, J. / Rocamora, A. (2006): The field of fashion realized. A study of London Fashion Week. In: Sociology, (40)4, 735-751.

FAulconbridge, J. (2006): Stretching tacit knowledge beyond a local fix? Global spaces of learning in advertising professional service firms. In: Journal of Economic Geography, (6)4, 517-540.

FAUlConBridge, J. (2008): Managing the transnational law firm. A relational analysis of professional systems, embedded actors and time-space sensitive governance. In: Economic Geography, (84)2, 185-210.

FLETCHER, D.E. (2006): Entrepreneurial processes and the social construction of opportunity In: Entrepreneurship \& Regional Development: An International Journal, (18)5, 421-440.

Foucault, M. (2000 [1984]): Michel Foucault - Aesthetics: Essential Works of Michel Foucault 1954-1864. London.

FriedLAND, R. / ALFORD, R. (1991): Bringing society back in. Symbols, practices, and institutional contradictions. In: Powell, W. W. / DiMaggio, P. J. (Eds.): The new institutionalism in organizational analysis. London, 232-263.

Friedman, T.L. (2006): The world is flat. The globalized world in the twenty-first century. London.

GARUD, R. (2008): Conferences as venues for the configuration of emerging organizational fields. The case of cochlear implants. In: Journal of Management Studies, (45)6, 10611088. 
Gertler, M. (2003): Tacit knowledge and the economic geography of context, or the undefinable tacitness of being. In: Journal of Economic Geography, (3)1, 75-99.

GetZ, D. (1989): Special events. Defining the product. In: Tourism Management, (10)2, 135-137.

GidDENS, A. (1984): Die Klassenstruktur fortgeschrittener Gesellschaften. Frankfurt am Main.

GLÜCKLER, J. (2006): A relational assessment of international market entry in management consulting. In: Journal of Economic Geography, (6)3, 369-393.

GLÜCKLER, J. (2007): Geography of reputation. The city as the locus of business opportunity. In: Regional Studies, (41)7, 949-961.

GLYNN, M.A. (2008): Configuring the field of play. How hosting the Olympic Games impacts civic community. In: Journal of Management Studies, (45)6, 1117-1146.

Goldstone, J.A. (2004): More social movements or fewer? Beyond political opportunity structures to relational fields. In: Theory and Society, (33)3/4, 333-365.

GraBHER, G. (2002): Fragile sector, robust practice. Project ecologies in new media. In: Environment and Planning A, (34)11, 1911-1926.

GRABHER, G. (2004): Learning in projects, remembering in networks? Communality, sociality, and connectivity in project ecologies. In: European Urban and Regional Studies, (11)2, 103-123.

HALL, M. (1989): The definition and analysis of hallmark tourist events. In: GeoJournal, (19)3, 263-268.

Hardy, C. / Maguire, S. (2010): Discourse, field-configuring events, and change in organizations and institutional fields. Narratives of DDT and the Stockholm convention. In: Academy of Management Journal, (53)6, 1365-1392.

Helbrecht, I. (1998): The creative metropolis. Services, symbols, and spaces. In: International Journal of Architectural Theory, (3)1, 1-10.

Hernes, T. (2003): Organization as evolution of space. In: Czarniawska, G. / Sevon, G. (Eds.): Northern lights. Organization theory in Scandinavia. Copenhagen, 267-290.

HJoRTH, D. (2004): Creating space for play-invention - concepts of space and organizational entrepreneurship. In: Entrepreneurship and Regional Development, (16)5, 413-432.

HJoRTH, D. (2005): Organizational entrepreneurship. With de Certeau on creating heterotopias (or spaces for play). In: Journal of Management Inquiry, (14)4, 386-398.

Howells, J. R. L. (2002): Tacit knowledge, innovation and economic geography. In: Urban studies, (39)5/6, 871-884.

IAMMARINO, S. / McCANN, P. (2013): Multinationals and economic geography. Location, technology and innovation. Cheltenham, UK.

IBERT, O. (2006): Zur Lokalisierung von Wissen durch Praxis. Die Konstitution von Orten des Lernens über Routinen, Objekte und Zirkulation. In: Geographische Zeitschrift, (94) $2,98-115$.

IBert, O. / Thiel, J. (2009): Situierte Analyse, dynamische Räumlichkeiten. Anknüpfungspunkte, Perspektiven und Potentiale einer Zeitgeographie wissensbasierter Ökonomien. In: Zeitschrift für Wirtschaftsgeographie, (53)4, 209-223.
JANSSON, J./ POWER, D. (2010): Fashioning a global city. Creating and maintaining global city status in the fashion and design industries, the case of Milan. In: Regional Studies, (44)7, 889-904.

Jones, C. / AnAnd, N. / Alvarez, J. L. (2005): Manufactured authenticity and creative voice in cultural industries. In: Journal of Management Studies, (42)5, 893-900.

Knoben, J./ Oerlemans, L.A.G. (2006): Proximity and inter-organizational collaboration - a literature review. In: International Journal of Management Reviews, (8)2, 71-89.

LAMPEL, J. (2011): Converting values into other values. Fairs and festivals as resource valuation and trading events. In: Moeran, B. / Strandgaard Pedersen, J. (Eds.): Negotiating values in the creative industries. Fairs, festivals and competitive events. Cambridge, 334-345.

LAMPEL, J. / MEYER, A. D. (2008): Guest editor's introduction: Field-configuring events as structuring mechanisms. How conferences, ceremonies, and trade shows constitute new technologies, industries, and markets. In: Journal of Management Studies, (45)6, 1025-1035.

LANG, G. (2003): Time Konvergenz. Einige Überlegungen aus volkswirtschaftlicher Sicht. In: Karmasin, M./Winter, C. (Hrsg.): Konvergenz und Management. Eine Einführung in die zentralen Herausforderungen und Aufgaben. München, 93-111.

LANGE, B. (2011): Field configuring events. Spatial politics and professional scene formation in the design segment of Berlin. In: Koch, G. (Hrsg.): Arbeit und Alltag. Frankfurt am Main, 59-80.

LANGE, B. / BÜRKNER, H.-J. (2013): Value-creation in the creative economy. The case of electronic club music in Germany. In: Economic Geography, (82)2, 149-169.

LANGE, B. / BÜTTNER, K. (2010): Spatialisation patterns of translocal knowledge networks. Conceptual understandings and empirical evidences of Erlangen and Frankfurt/Oder. In: European Planning Studies, (18)6, 989-1018.

Lange, B. / Kalandides, A. / StöBer, B. / Mieg, H.A. (2008): Berlin's creative industries - governing creativity? In: Industry and Innovation, (15)5, 531-548.

LAWRENCE, T. B. / SudDABy, R. ( $\left.{ }^{2} 2006\right)$ : Institutions and institutional work. In: Clegg, S. R. / Hardy, C. / Lawrence, T. / Nord, W.R. (Eds): The Sage Handbook of Organization Studies. London, 215-254.

LENA, J.C. (2011): Tradition and transformation at the Fan Fair Festival. In: Moeran, B./Strandgaard Pedersen, J. (Eds.): Negotiating values in the creative industries. Fairs, festivals and competitive events. Cambridge, 224-248.

Levy, D. / Scully, M. (2007): The institutional entrepreneur as modern prince. The strategic face of power in contested fields. In: Organization Studies, (28)7, 971-991.

LEWIN, K. (1951). Field theory in social science. New York. LEY, D. / OLDS, K. (1988): Landscape as spectacle: world's fairs and the culture of heroic consumption. In: Environment and Planning D: Society and Space, (6)10, 191-212.

Lounsbury, M. / VentrescA, M. / Hirsch, P. M. (2003): Social movements, field frames and industry emergence: a cultural-political perspective on US recycling. In: SocioEconomic Review, (1)1, 71-104. 
Löw, M. (2008): The constitution of space. The structuration of spaces through the simultaneity of effect and perception. In: European Journal of Social Theory, (11)1, 25-49.

LuNDVALL, B.-Å. (Ed.) (1992): National systems of innovation. Towards a theory of innovation and interactive learning. London.

Marquis, C. / Glynn, M.A. / Davis, G. (2007): Community isomorphism and corporate social action. In: Academy of Management Review, (32)3, 925-945.

Maskell, P. / Bathelt, H. / Malmberg, A. (2004): Temporary clusters and knowledge creation. The effects of international trade fairs, conventions and other professional gatherings. Marburg. (Spaces, 2004/4).

Maskell, P. / Bathelt, H. / Malmberg, A. (2006): Building global knowledge pipelines. The role of temporary clusters. In: European Planning Studies, (14)8, 997-1014.

MCINERNEY, P. (2008): Showdown at Kykuit. Field-configuring events as loci for conventionalizing accounts. In: Journal of Management Studies, (45)6, 1089-1116.

McRobile, A. (2002): Clubs to companies. Notes on the decline of political culture in speeded up creative. In: Bittner, R. (Hrsg.): Die Stadt als Event. Frankfurt am Main, 475484.

Meyer, A. D. / Gaba, V. / Colwell, K.A. (2005): Organizing far from equilibrium: Nonlinear change in organizational fields. In: Organization Science, (16)5, 456-473.

Mezias, S. J. / Pedersen, J. S. / Kim, J.-H. / Svejenova, S. / MAzZA, C. (2011): Transforming film product identities. The status effects of European premier film festivals, 1996 2005. In: Moeran, B. / Strandgaard Pedersen. J. (Eds.): Negotiating values in the creative industries. Fairs, festivals and other competitive events. Cambridge, 169-196.

Moeran, B. / StrandgaArd Pedersen, J. (2011): Introduction. In: Moeran, B. / Strandgaard Pedersen, J. (Eds.): Negotiating values in the creative industries. Fairs, festivals and competitive events. Cambridge, 1-35.

Moeran, B. (2011): The book fair as tournaments of value. In: Moeran, B. / Strandgaard Pedersen, J. (Eds.): Negotiating values in the creative industries. Fairs, festivals and competitive events. Cambridge, 119-144.

MöLlering, G. (2011): Umweltbeeinflussung durch Events? Institutionalisierungsarbeit und feldkonfigurierende Veranstaltungen in organisationalen Feldern. In: Schmalenbachs Zeitschrift für betriebswirtschaftliche Forschung, (63) August, 458-484.

NAVIS, C. / GLYNN, M.A. (2010): How new market categories emerge. Temporal dynamics of legitimacy, identity, and entrepreneurship in satellite radio, 1990-2005. In: Administrative Science Quarterly, (55)3, 439-471.

OLDS, K. (1998): Urban mega-events, evictions and housing rights. The Canadian case. In: Current Issues in Tourism, (1) $1,2-46$

Paleo, I. O. / Wijnberg, N. M. (2006): Classification of popular music festivals. A typology of festivals and an inquiry into their role in the construction of music genres. In: International Journal of Arts Management, (8)2, 50-61.

PIKE, A. (Ed.) (2011): Brands and branding geographies. London.
PORTER, M. (1990): The competitive advantage of nations. London.

Power, D. / JAnsson, J. (2008): Cyclical clusters in global circuits. Overlapping spaces in furniture trade fairs. In: Economic Geography, (84)4, 423-448.

Power, D. / ScotT, A. J. (2004): A prelude to cultural industries and the production of culture. In: Power, D. / Scott, A. J. (Eds.): Cultural industries and the production of culture. London, 3-16. (Routledge studies in international business and the world economy).

Pratt, A. (2009): The challenge of governance in the creative and cultural industries. In: Lange, L. / Kalandides, A. / Stöber, B. / Wellmann, I. (Hrsg.): Governance der Kreativwirtschaft. Bielefeld, 271-288.

Rüling, C.-C./ StrandgaArd Pedersen, J. (2010): Film festival research from an organizational studies perspective. In: Scandinavian Journal of Management, (26)3, 318-323.

SAssen, S. (1991): The global city: New York, London, Tokyo. Princeton.

Schuldt, N. / BAthelt, H. (2009): Reflexive Zeit- und Raumkonstruktionen und die Rolle des Global Buzz auf Messeveranstaltungen. In: Zeitschrift für Wirtschaftsgeographie, (53)4, 235-248.

Schüssler, E. / Rüling, C.-C. / Wittneben, B. (2013): On melting summits. The limitations of field-configuring events as catalysts of change in transnational climate policy. In: Academy of Management Journal, doi: 10.5465/ amj.2011.0812.

SChÜSSLER, E. / DoBusch, L. (2013): Musikevents als Bühnen für den Urheberrechtsdiskurs. In: Lange, B. / Bürkner, H.-J. / Schüßler, E. (Hrsg.): Akustisches Kapital. Perspektiven auf veränderte Wertschöpfungskonfigurationen. Bielefeld, 247-276.

ScotT, A. J. (1999): The cultural economy. Geography and the creative field. In: Media Culture \& Society, (21)6, 807818 .

ScotT, A. J. (2005): On Hollywood. The place, the industry. Princeton.

ScotT, A.J. (2006): Entrepreneurship, innovation and industrial development. Geography and the creative field revisited. In: Small Business Economics, (26)1, 1-24.

ScotT, A. J. (2010): Cultural economy and the creative field of the city. In: Geografiska Annaler - Series B, Human Geography, (92)2, 115-130.

Scotт, W. R. (1994): Institutions and organizations. Toward a theoretical synthesis. In: Scott, W. R. / Meyer, J. W. (Eds.): Institutional environments and organizations: Structural complexity and individualism. London, 55-80.

ScotT, W. R. (2003): Institutional carriers. Reviewing modes of transporting ideas over time and space and considering their consequences. In: Industrial and Corporate Change, (12)4, 879-894.

Skov, L. (2006): The role of trade fairs in the global fashion business. In: Current Sociology, (54)5, 764-783.

Skov, L. / MeIER, J. (2011): Configuring sustainability at fashion week. In: Moeran, B./ Strandgaard Pedersen, J. (Eds.): Negotiating values in the creative industries. Fairs, festivals and competitive events. Cambridge, 270-293. 
Stevenson, D. / Rowe, D. / Markwell, K. (2005): Explorations in 'event technology'. The case of the International Gay Games. In: Social Identities (11)5, 447-465.

STEYAert, C. / HJoRTh, D. (2003): New movements in entrepreneurship. Cheltenham, UK; Northampton, MA.

Steyaert, C./KatZ, J. (2004): Reclaiming the space of entrepreneurship in society. Geographical, discursive and social dimensions. In: Entrepreneurship and regional development, (16)3, 179-196.

Storper, M./Venables, A.J. (2004): Buzz: face-to-face contact and the urban economy. In: Journal of Economic Geography, (4)4, 351-370.

Suwala, L. (2012): Kreativität, Kultur und Raum. Ein wirtschaftsgeographischer Beitrag am Beispiel des kulturellen Kreativitätsprozesses. Wiesbaden.
Sydow, J. / LindKvist, L. / DeFillipPI, R. (2004): Projectbased organizations, embeddedness and repositories of knowledge. Editorial. In: Organization Studies, (25)9, $1475-1490$.

Thompson, D. (2011): Art fairs. The market is medium. In: Moeran, B. / Strandgaard Pedersen, J. (Eds.): Negotiating values in the creative industries. Fairs, festivals and other competitive events. Cambridge, 59-72.

WELLER, S. (2007): Fashion as viscous knowledge. Fashion's role in shaping trans-national garment production. In: Journal of Economic Geography, (7)1, 39-66.

ZiLBER, T.B. (2007): Stories and the discursive dynamics of institutional entrepreneurship. The case of Israeli hightech after the bubble. In: Organization Studies, (28)7, 10351054. 